\title{
TYPPI- JA KALILANNOITUKSEN VAIKUTUS RUOKAPERUNAN LAATUUN
}

\author{
Anita Ellala, Lasse Vanhanen ja Rakel Kurkela \\ Elintarvikekemian ja -teknologian laitos, Helsingin Yliopisto
}

Saapunut 3. 7. 1970

THE INFLUENCE OF NITROGEN AND POTASSIUM FERTILIZING ON THE SPECIFIC GRAVITY AND COOKING QUALITY OF POTATO VARIETIES BINTJE AND REALTA

\author{
Anita Ellala, Lasse Vanhanen and Rakel Kurkela \\ Helsinki University, Institut of Food Chemistry and Technology
}

\begin{abstract}
The influence of three nitrogen and potassium levels on the specific gravity and cooking quality of the varieties Bintje and Realta in the year 1968 was investigated. In order to find out the influence of two different kinds of soil the potatoes were grown in fine sandy soil rich in organic matter (Mikkeli) and sandy gyttja clay (Vehkalahti). The potatoes were fertilized with 50,125 and $200 \mathrm{~kg} \mathrm{~N} / \mathrm{ha}$, every rate of nitrogen combined with 100,200 and $400 \mathrm{~kg} \mathrm{~K} / \mathrm{O} / \mathrm{ha}$.

Mealiness and flavour were evaluated from the samples fractioned into five specific gravity classes. On the basis of sensory evalutation of the different classes the amount of potatoes of high quality was calculated from all the samples. The mealiness and flavour of the potatoes representing the specific gravity class of highest total weight were considered characteristic to the sample. The specific gravity, darkening after cooking and stability of prepeeled potatoes, were also regarded as a criteria of the quality.

The mean specific gravity of both varieties was lowered by nitrogen and potassium fertilizing. Similarly, the characteristic mealiness of the sample and the amount of high quality potatoes decreased with increased fertilizing. However, even the strongest fertilizing did not cause any perceptible off-flavor, although the potatoes of the strongest NK-application were differentiated from those of the weakest NK-application by triangle tests.

Nitrogen or potassium fertilizing did not affect the stability of colour of pre-peeled potatoes, when discoloration was controlled once a day during storage.

The effect of the variety of soil was stronger than that of fertilizing on the quality of both potato varieties.
\end{abstract}

Perunan lannoituksella päästään varsin huomattaviin sadon lisäyksiin, mutta samalla on todettu lannoituksen vaikuttavan myös sadon laatuun. Lannoituksen aiheuttamia laadun muutoksia on selvitetty paitsi Yhdysvalloissa myös Euroopassa mm. Hollannissa (Schippers 1961, 1968a, 1968b), Saksassa (Arenz ym. 1960, Schmitt ja Brauer 1964, Soll 1961), Norjassa (Andersen 1966, Baerug 1961, Hernes ja Elle 1961), Ruotsissa (Agerberg ja Svensson 1961, Andersson ym. 1964, Johansson 1966, Lomakka 1966, Svensson 1964) ja Suomessa (LÄHDE 1935, VARIs 1968). VARIs (1970 a ja b) on referoinut näitä tutkimuksia perusteellisesti. 
Useimmissa tutkimuksissa on laadun kriteerinä pidetty perunan ominaispainoa, kuivaaine- tai tärkkelyspitoisuutta. Joissakin tutkimuksissa on lisäksi kiinnitetty huomiota perunan keitto-ominaisuuksiin (cooking quality): makuun, rakenteeseen ja keiton jälkeiseen tummumiseen.

Tässä tutkimuksessa on selvitetty typpi- ja kalilannoituksen vaikutusta Bintjen ja Realtan laatuun. Nämä lajikkeet valittiin tutkimuksen kohteeksi, koska ne tällä hetkellä tietyiltä ominaisuuksiltaan sopivat hyvin ruokaperunaa jalostavan teollisuuden raakaaineeksi. Laadun kriteerinä ominaispainon ja keitto-ominaisuuksien lisäksi on pidetty perunan säilyvyyttä kuorittuna.

\section{Materiaali}

Tutkimuksessa käytettiin Itä-Suomen Raakasokeritehdas Oy:n kesällä -68 tekemän perunan typpi- ja kalilannoituksen tarvetta selvittävän kenttäkokeen materiaalia. Kokeessa olleet lajikkeet, Bintje ja Realta, viljeltiin kahdella eri kasvupaikalla, Mikkelin mlk:ssa ja Vehkalahdella, yhdeksällä eri lannoitustasolla (36 koejäsentä). Mikkelin mlk:ssa oli maanlaatu multava hietamaa ja Vehkalahdella hietainen urpasavi. Kummankin kasvupaikan maaperän viljavuustutkimuksen tulokset ovat taulukossa 1. Typpilannoitteena oli Oulunsalpietari, kalilannoitteena kaliumsulfaatti ja fosforilannoitteena superfosfaatti. Kokeissa käytetty typpilannoitus oli 50, 125 ja $200 \mathrm{~kg} \mathrm{~N} /$ ha, kukin yhdistettynä kolmeen eri kalilannoitustasoon; 100, 200 ja 400 kg K ${ }_{2} \mathrm{O} / \mathrm{ha}$.

Fosforilannoitus oli kaikilla lannoitustasoilla sama: $285 \mathrm{~kg} \mathrm{P}_{2} \mathrm{O}_{5} /$ ha. Bintje viljeltiin hollantilaisesta, virustestatusta siemenestä. Yksityiskohtaiset tiedot kenttäkokeen järjestämisestä ja viljelytekniikasta käyvät selville Itä-Suomen Raakasokeritehdas Oy:n kesän -68 perunanviljelykokeiden raportista (Itä-Suomen Raakasokeritehdas Oy. 1968).

Noston yhteydessä perunat lajiteltiin kolmeen eri kokoluokkaan $25-35 \mathrm{~mm}, 35-55$ $\mathrm{mm}$ ja $>55 \mathrm{~mm}$. Satotulokset on esitetty kuvissa 1 ja 2.

Laadun arvostelua varten saatiin kustakin koejäsenestä $50 \mathrm{~kg}$ :n näyte kokoluokasta $35-55 \mathrm{~mm}$. Perunoita oli varastoitu $4 \mathrm{kk} 4-6^{\circ} \mathrm{C}: s s a 85 \% \mathrm{rH}: s s a$ ennen tämän tutkimuksen suorittamista.

Taulukko 1. Maaperän viljavuustutkimuksen tulokset Itä-Suomen Raakasokeritehdas Oy:n perunan viljelyn kenttäkokeiden kasvualustoista Vehkalahdelta ja Mikkelistä tutkittuna keväällä ja syksyllä 1968 otettujen maanäytteiden perusteella.

\begin{tabular}{|c|c|c|c|c|}
\hline & \multicolumn{2}{|c|}{ Vehkalahti } & \multicolumn{2}{|c|}{ Mikkeli } \\
\hline & kevät & syksy & kevät & syksy \\
\hline & 1968 & 1968 & 1968 & 1968 \\
\hline Johtoluku & 0.4 & 3.7 & - & 0.8 \\
\hline $\mathrm{pH}$ & 5.0 & 4.8 & 5.2 & 4.3 \\
\hline Kalsium $\mathrm{mg} / \mathrm{l}$ & 1298.0 & 2332.0 & 550.0 & 2310.0 \\
\hline Fosfori $\quad \mathrm{mg} / \mathrm{l}$ & 3.9 & 5.0 & 1.0 & 8.0 \\
\hline Kalium $\mathrm{mg} / \mathrm{l}$ & 84.0 & 273.0 & 50.0 & 90.0 \\
\hline
\end{tabular}



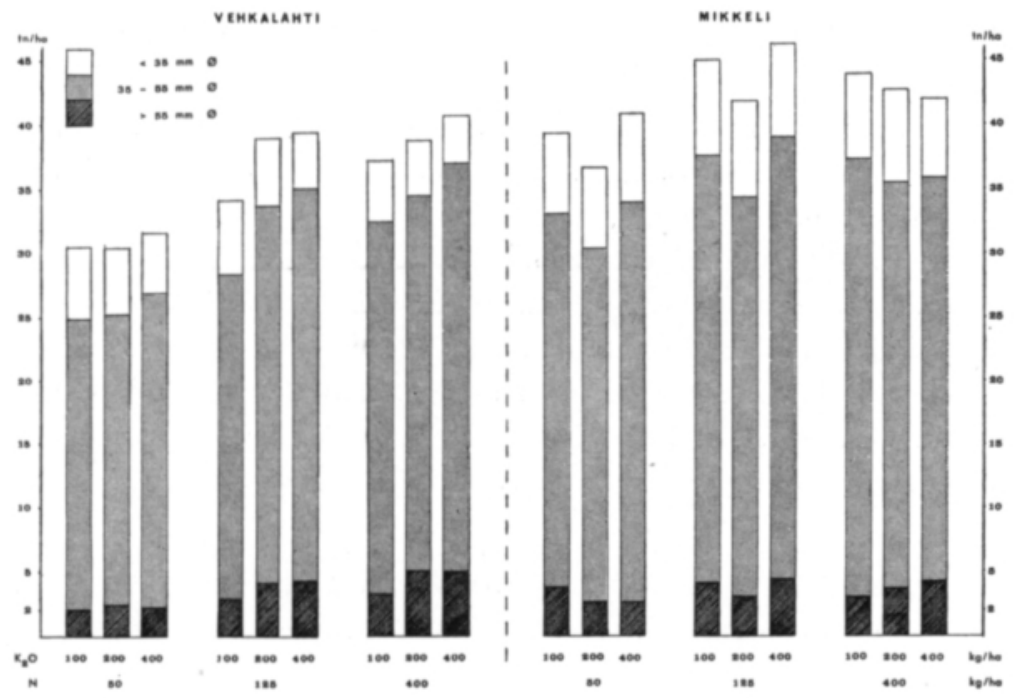

Kuva 1. Bintjen kokonaissato hietaisella urpasavella (Vehkalahti) ja multavalla hietamaalla (Mikkeli) eri lannoitustasoilla.
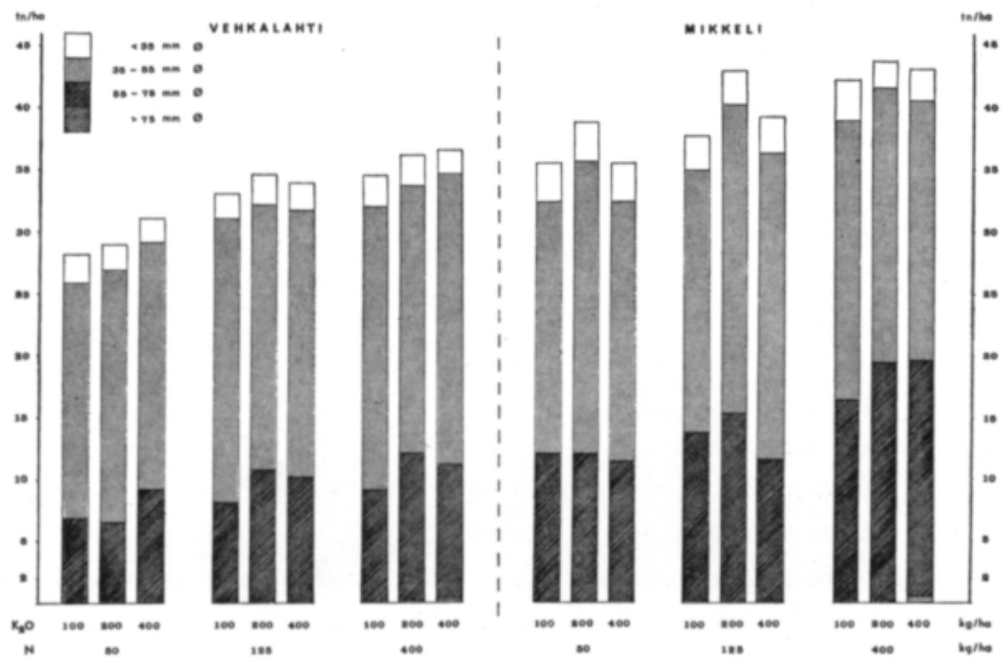

Kuva 2. Realtan kokonaissato hietaisella urpasavella (Vehkalahti) ja multavalla hietamaalla (Mikkeli) eri lannoitustasoilla.

\section{Menetelmät}

Laadun arvostelemiseksi määritettiin keskimääräinen ominaispaino ja ominaispainojakautuma sekä suoritettiin maun ja jauhoisuuden arvostelu. Näiden perusteella laskettiin moitteettoman ruokaperunan osuus eri koejäsenissä. Lisäksi tutkittiin koejäsenistä keiton jälkeinen tummuminen ja värin säilyvyys kuorittuna sulfiittikäsittelyn jälkeen. 
K e s k i m ä ä rä i n e n o m i n a is p a i n o. Koejäsenistä määritettiin keskimääräinen ominaispaino punnitsemalla $8 \mathrm{~kg}: \mathrm{n}$ näyte ilmassa ja vedessä.

O min a is pain oja k a u t u m a määritettiin koejäsenistä lajittelemalla materiaali suolaliuoksilla kuuteen eri ominaispainoluokkaan $(<1.065,1.065-1.075,1.075$ $1.080,1.080-1.085,1.085-1.095,>1.095)$.

Ominaispainolajiteltua materiaalia käytettiin myös maun ja jauhoisuuden arvostelussa. Aikaisemman kokemuksen perusteella fraktio 1.075-1.085 oli osoittautunut kriittiseksi ominaispainoalueeksi määritettäessä eri perunalajikkeiden ruokaperunakelpoisuutta, minkä vuoksi tämä fraktio jaettiin kahteen osaan (1.075-1.080, 1.080-1.085). Realtan kohdalla osoittautui fraktio 1.085-1.095 kriittiseksi ruokaperunakelpoisuutta määritettäessä, minkä vuoksi Realtasta tämä fraktio jaettiin kahteen osaan (1.085—1.090, $1.090-1.095)$.

M a k u j ja u ho is u u s. Maun ja jauhoisuuden arvostelu tehtiin ominaispainolajitellusta materiaalista samoin kuin pestyn perunan säilyvyyttä koskevassa tutkimuksessa (Ellala ym. 1970).

Jauhoisuuden arvostelussa käytettiin LugTın ja Goodıjkın menetelmästä muunnettua asteikkoa (Lugr ja Goodjuk 1959).

— erittäin jauhoinen

- jauhoinen

- hiukan jauhoinen

- kiinteä, tahmea, ei jauhoinen

— vetinen, pehmeä, löysä.

Tulosten laskemista varten annettiin kullekin jauhoisuusasteella pisteet seuraavasti: erittäin jauhoinen 4, jauhoinen 3 , hiukan jauhoinen 2.5, kiinteä, tahmea 2 ja vetinen, löysä 1 .

Maun arvostelussa käytettiin asteikkoa:

— hyvä, täyteläinen perunan maku

— tyydyttävä, laimea perunan maku, ei sivumakua

— välttävä, lievä sivumaku

— huono, voimakas sivumaku.

Samoin kuin jauhoisuuden arvostelussa annettiin tulosten laskemista varten pisteet kullekin makuasteelle seuraavasti: hyvä 4, tyydyttävä 3, välttävä 2 ja huono 1 . Maultaan ja jauhoisuudeltaan moitteettomana pidettiin näytettä, joka sai arvostelussa ryhmän antamaksi keskiarvoksi $\geqq 2.5$ pistettä sekä mausta että jauhoisuudesta.

Moit te et toman ruokaperunan osu us ilmoittaa, montako prosenttia kustakin koejäsenestä on materiaalia, joka on saanut maun ja jauhoisuuden arvostelussa $\geqq 2.5$ pistettä. Kustakin koejäsenestä arvosteltiin maku ja jauhoisuus ominaispainofraktioittain. Täten määritettiin ominaispainoraja, josta lähtien maku ja jauhoisuus täyttivät asetetut vähimmäisvaatimukset $(\geqq 2.5)$. Ominaispainojakautuman perusteella laskettiin tämän rajan yläpuolella olevan materiaalin osuus, jolloin saatiin selville moitteetoman ruokaperunan osuus kussakin koejäsenessä.

Kunkin koejäsenen o min a is ma k u a ja - ja u ho is u u t a kuvaavat painomäärältään suurimman ominaispainoluokan saamat maku- ja jauhoisuuspisteet. Lannoituksen vaikutus makuun ja jauhoisuuteen testattiin varianssianalyysillä. 
Taulukko 2. Hietaisella urpasavella (Vehkalahti) ja multavalla hietamaalla (Mikkeli) eri lannoitustasoilla viljellyn Bintjen ja Realtan keskimääräiset ominaispainot.

\begin{tabular}{cccccc}
\hline \multicolumn{2}{c}{ Lannoitustaso } & \multicolumn{2}{c}{ Bintje } & \multicolumn{2}{c}{ Realta } \\
\hline $\begin{array}{c}\mathrm{N} \\
\mathrm{kg} / \mathrm{ha}\end{array}$ & $\begin{array}{c}\mathrm{K}_{2} \mathrm{O} \\
\mathrm{kg} / \mathrm{ha}\end{array}$ & Vehkalahti & Mikkeli & Vehkalahti & Mikkeli \\
& 100 & 1.099 & 1.082 & 1.097 & 1.082 \\
& 200 & 1.095 & 1.083 & 1.093 & 1.080 \\
50 & 400 & 1.093 & 1.074 & 1.093 & 1.074 \\
& 100 & 1.092 & 1.078 & 1.097 & 1.072 \\
& 200 & 1.087 & 1.075 & 1.094 & 1.070 \\
& 400 & 1.080 & 1.072 & 1.091 & 1.070 \\
& & & & & \\
& 100 & 1.087 & 1.067 & 1.094 & 1.070 \\
& 200 & 1.087 & 1.070 & 1.092 & 1.070 \\
& 400 & 1.083 & 1.070 & 1.091 & 1.070 \\
& & & & & 1.073 \\
\hline
\end{tabular}

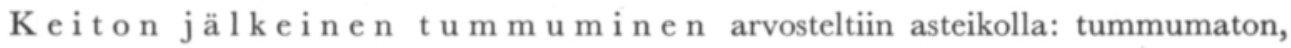
hyvin lievästi tummunut, hiukan tummunut, pahasti tummunut, pilalle tummunut. Lannoituksen vaikutus keiton jälkeiseen tummumiseen testattiin niin ikään varianssianalyysillä.

Kuoritun perunan säilyvyyden tutkimista varten kuorittiin $8 \mathrm{~kg}: \mathrm{n}$ erä kustakin koejäsenestä teräkuorijalla (Solia Tempo S 8) ja suoritettiin jälkipuhdistus käsin. Puolet näytteistä käsiteltiin $0.25 \%$ :sella $\mathrm{NaHSO}_{3}$-liuoksella ja puolet $0.50 \%$ :sella $\mathrm{NaHSO}_{3}$-liuoksella. Käsittelyaika oli 30 sek. Perunat pakattiin $0.08 \mathrm{~mm}: \mathrm{n}$ vahvuiseen läpinäkyvään polyeteenipussiin ja varastoitiin $4-6^{\circ} \mathrm{C}$ :ssa. Keskenään verrattavat näytteet valmistettiin samana päivänä.

Tuloksissa ilmoitetaan, montako vuorokautta perunat säilyivät ulkonäöltään hyväksyttävinä eli kun värivirheitä oli alle $10 \%$ :ssa mukuloita. Pakkaukset avattiin tietyn säilytysajan jälkeen ja tummuneiden perunoiden prosenttinen osuus laskettiin.

Triangelitestillä tutkittiin, aiheuttaako lannoitus koejäsenissä aistinvaraisesti todettavaa makueroa (Ellala ym. 1970).

\section{Kokeet ja tulokset}

Keskimäärinen ominaispaino ja ominaispainojakaut u m a. Keskimääräiset ominaispainot on esitetty taulukossa 2 ja ominaispainojakautumat kuvassa 3.

Keskimääräisten ominaispainojen keskiarvot eri typpi- ja kalitasoilla olivat

$\begin{array}{cccc}\mathrm{N} \mathrm{kg} / \mathrm{ha} & \overline{\mathrm{x}} & \mathrm{K}_{2} \mathrm{O} \mathrm{kg} / \mathrm{ha} & \overline{\mathrm{x}} \\ 50 & 1.087 & 100 & 1.085 \\ 125 & 1.082 & 200 & 1.083 \\ 200 & 1.079 & 400 & 1.081\end{array}$



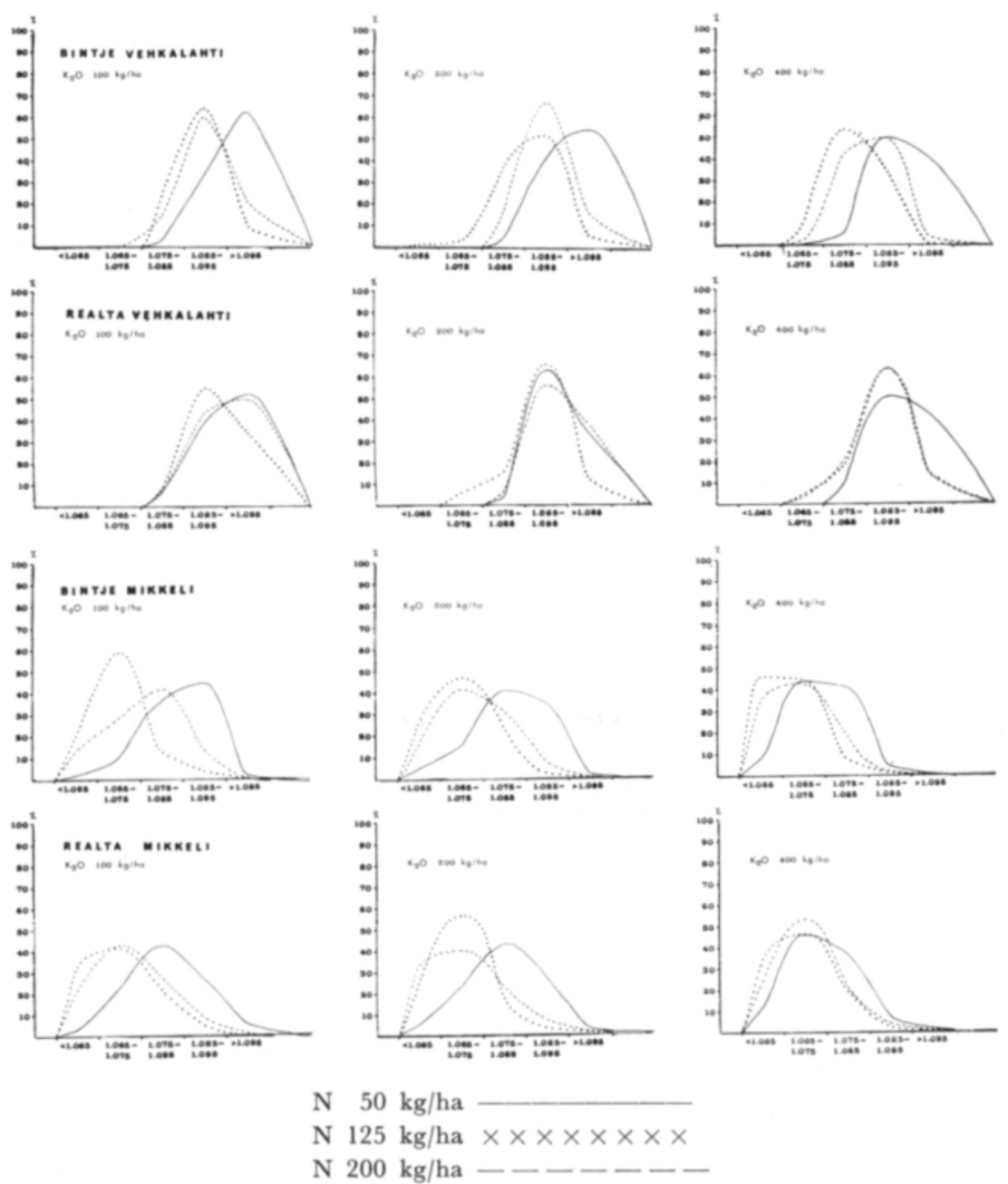

Kuva 3. Hietaisella urpasavella (Vehkalahti) ja multavalla hietamaalla (Mikkeli) eri lannoitustasoilla viljellyn Bintjen ja Realtan ominaispainojakautumat.

Ominaispainon aleneminen lannoitusta lisättäessä näkyy myös ominaispainojakautuman huippukohdan siirtymisenä alhaisempaan ominaispainoon. Hietaisella urpasavella (Vehkalahti) kasvaneiden perunoiden ominaispaino oli suurempi kuin multavalla hietamaalla (Mikkeli) kasvaneiden perunoiden. Kuitenkin on huomattava, että pienin keskimääräinen ominaispaino oli molemmilla lajikkeilla n. 1.070.

$\mathrm{Maku}$ ja ja uhois u us. Jauhoisuus osoittautui laadun minimitekijäksi moitteettoman ruokaperunan osuutta määritettäessä.

Ominaispainon alaraja, josta lähtien peruna todettiin sekä maultaan että jauhoisuudeltaan moitteettomaksi oli

$\begin{array}{lll}\text { Bintje, hietainen urpasavi (Vehkalahti) } & 1.080 \\ \text { Realta, " } & \text { " } & 1.090 \\ \text { Bintje, multava hietamaa (Mikkeli) } & 1.080\end{array}$


Taulukko 3. Moitteettoman ruokaperunan määrä hietaisella urpasavella (Vehkalahti) ja multavalla hietamaalla (Mikkeli) viljellystä Bintjestä ja Realtasta eri lannoitustasoilta kokoluokasta $35-55 \mathrm{~mm}$.

\begin{tabular}{|c|c|c|c|c|c|c|c|c|c|}
\hline \multicolumn{2}{|c|}{ Lannoitustaso } & \multicolumn{4}{|c|}{ Bintje } & \multicolumn{4}{|c|}{ Realta } \\
\hline \multirow{2}{*}{$\begin{array}{c}\mathrm{N} \\
\mathrm{kg} / \mathrm{ha}\end{array}$} & \multirow{2}{*}{$\begin{array}{c}\mathrm{K}_{2} \mathrm{O} \\
\mathrm{kg} / \mathrm{ha}\end{array}$} & \multicolumn{2}{|c|}{ Vehkalahti } & \multicolumn{2}{|c|}{ Mikkeli } & \multicolumn{2}{|c|}{ Vehkalahti } & \multicolumn{2}{|c|}{ Mikkeli } \\
\hline & & $\%$ & $\mathrm{tn} / \mathrm{ha}$ & $\%$ & $\mathrm{tn} / \mathrm{ha}$ & $\%$ & $\operatorname{tn} / \mathrm{ha}$ & $\%$ & $\mathrm{tn} / \mathrm{ha}$ \\
\hline \multirow{3}{*}{50} & 100 & 98.2 & 22.6 & 65.8 & 19.3 & 85.3 & 16.2 & 0 & 0 \\
\hline & 200 & 98.4 & 22.3 & 57.6 & 15.7 & 70.9 & 14.5 & 0 & 0 \\
\hline & 400 & 95.5 & 24.0 & 16.5 & 5.2 & 70.2 & 14.0 & 0 & 0 \\
\hline \multirow{3}{*}{125} & 100 & 93.9 & 23.4 & 38.7 & 13.0 & 86.9 & 20.0 & 0 & 0 \\
\hline & 200 & 92.8 & 27.5 & 16.0 & 5.0 & 65.2 & 13.8 & 0 & 0 \\
\hline & 400 & 82.1 & 25.1 & 13.6 & 4.7 & 46.0 & 9.9 & 0 & 0 \\
\hline \multirow{4}{*}{200} & 100 & 92.2 & 26.7 & 8.7 & 2.9 & 65.0 & 14.9 & 0 & 0 \\
\hline & 200 & 77.5 & 22.9 & 11.3 & 3.5 & 63.6 & 13.9 & 0 & 0 \\
\hline & 400 & 67.8 & 21.0 & 1.0 & 0.3 & 47.1 & 11.2 & 0 & 0 \\
\hline & $\bar{x}$ & 88.7 & 23.9 & 25.5 & 7.7 & 66.7 & 14.3 & 0 & 0 \\
\hline
\end{tabular}

Realtasta ei saatu multavalla hietamaalla viljeltynä lainkaan moitteetonta ruokaperunaa, sillä korkeinkaan ominaispainoluokka $(>1.095)$ ei jauhoisuuden puolesta täyttänyt asetettuja minimivaatimuksia.

Ominaispainolajittelun ja moitteettoman ruokaperunan ominaispainoalarajan perusteella lasketut moitteettoman ruokaperunan $\%$ :set osuudet eri lannoitustasoilta on esitetty taulukossa 3, jossa lisäksi on Itä-Suomen Raakasokeritehdas Oy:n satotulosten perusteella lasketut moitteettoman ruokaperunan sadon määrät eri lannoitustasoilla.

Suurin moitteettoman ruokaperunan määrä (27.5 tn/ha) saatiin Bintjestä hietaisella urpasavella viljeltäessä lannoiteyhdistelmällä $125 \mathrm{~kg} \mathrm{~N} / \mathrm{ha}+200 \mathrm{~kg} \mathrm{~K} / 2 \mathrm{O} / \mathrm{ha}$ (taulukko 3, kuva 4). Realtasta saatiin samalta kasvupaikalta eniten moitteetonta ruokaperunaa (20 tn/ ha) lannoiteyhdistelmällä $125 \mathrm{~kg} \mathrm{~N} / \mathrm{ha}+100 \mathrm{~kg} \mathrm{~K} \mathrm{~K}_{2} \mathrm{O}$. Multavalla hietamaalla saatiin Bintjestä eniten moitteetonta ruokaperunaa lannoituksella $50 \mathrm{~kg} \mathrm{~N} / \mathrm{ha}+100 \mathrm{~kg} / \mathrm{ha}$ (19.3 tn/ha). Kuten edellä kävi ilmi, Realtasta ei saatu tältä kasvupaikalta lainkaan moitteetonta ruokaperunaa, huolimatta siitä, että Realtan kokonaissato oli multavalla hietamaalla suurempi kuin urpasavella viljeltäessä (taulukko 3, kuva 4).

Moitteettoman ruokaperunan määrät (eri lannoitustasojen keskiarvot) olivat

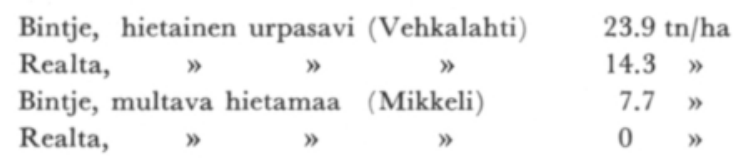

Hietaiselta urpasavelta saatiin yhteensä molemmista lajikkeista $38.2 \mathrm{tn} /$ ha moitteetonta ruokaperunaa ja multavalla hietamaalla $7.7 \mathrm{tn} / \mathrm{ha}$. Tulosten mukaan Realta oli herkempi kasvupaikan muutoksille kuin Bintje. 


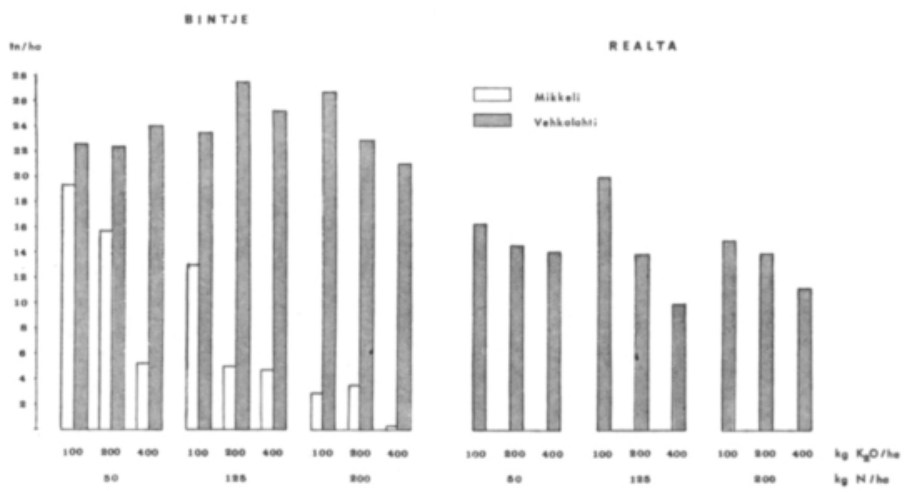

Kuva 4. Moitteettoman ruokaperunan määrä tn/ha hietaisella urpasavella (Vehkalahti) ja multavalla hietamaalla (Mikkeli) viljellystä Bintjestä ja Realtasta eri lannoitustasoilta kokoluokasta $35-55 \mathrm{~mm}$.

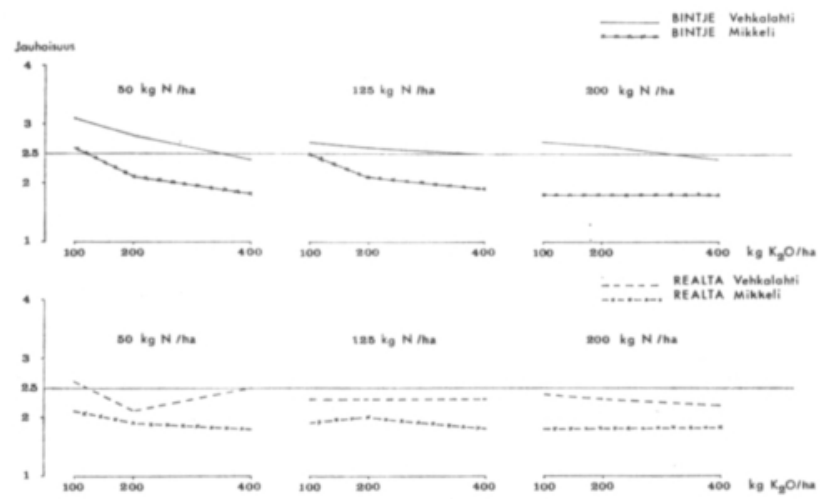

Kuva 5. Kalilannoituksen vaikutus hietaisella urpasavella (Vehkalahti) ja multavalla hietamaalla (Mikkeli) eri typpilannoitustasoilla viljellyn Bintjen ja Realtan jauhoisuuteen.
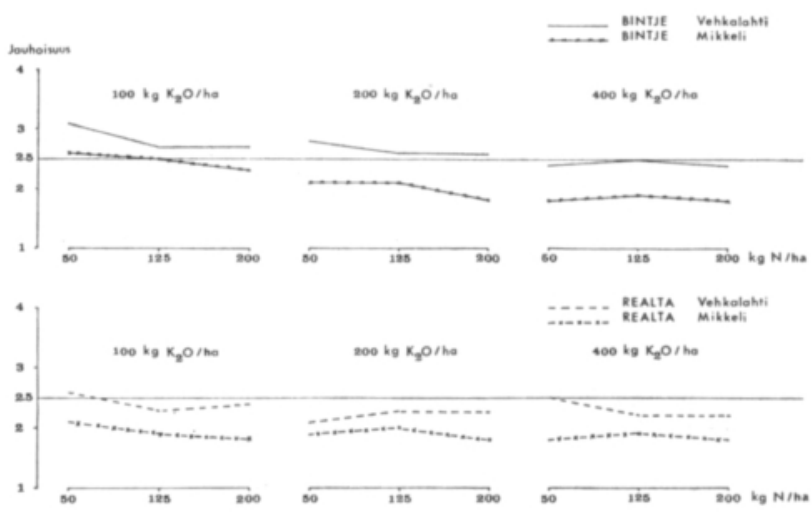

Kuva 6. Typpilannoituksen vaikutus hietaisella urpasavella (Vehkalahti) ja multavalla hietamaalla (Mikkeli) eri kalilannoitustasoilla viljellyn Bintjen ja Realtan jauhoisuuteen. 
Ominaisjauhoisuuden tulokset ovat kuvissa 5 ja 6. Sekä typpi- että kalilannoituksen lisäämisellä oli jauhoisuutta alentava vaikutus, joskaan erot eri lannoitustasojen kesken eivät olleet tilastollisesti merkitseviä. Lannoituksen makua huonontava vaikutus ei niinikään ollut tilastollisesti merkitsevä.

$\mathrm{K}$ e i t on jäl ke in e n $\mathrm{t}$ u m m u m in e n. Keitonjälkeisen tummumisen määrittämisessä saadut tulokset on esitetty taulukoissa 4-5. Tummumistaipumus tulee selvemmin näkyviin kuorineen keitetyistä perunoista kuin kuorittuna keitetyistä, joista kuorittaessa poistuu tummumiselle alttein osa (taulukot 4 ja 5). Lannoituksen vaikutus keiton jälkeiseen tummumiseen kuorineen keitetyistä perunoista arvosteltuna oli tilastollisesti merkitsevä mutta ei sen sijaan kuorittuna keitetyistä perunoista arvosteltuna.

Kuoritun perunan säilyvyys. Vuorokauden välein tehdyt arvostelut osoittivat, että ensimmäisenä värivirheenä tuli perunoihin sinertävänä värinä ilmenevä tummuminen, jota oli useimmiten pienellä alueella perunan kulmissa. Vasta useiden vuorokausien varastoinnin jälkeen ilmaantui kauttaaltaan pinnan peittävä ruskehtava väri.

Värivirheitä esiintyi eniten pienimmällä kalilannoituksella (100 kg $\mathrm{K}_{2} \mathrm{O} / \mathrm{ha}$ ), mutta erot eri lannoitustasojen perunoiden välillä eivät olleet niin suuria, että ne olisivat aiheuttaneet eroja säilyvyysaikoihin tarkastuksen tapahtuessa vuorokauden välein.

Säilyvyysajat olivat:

\begin{tabular}{|c|c|c|}
\hline & $\begin{array}{c}0.25 \% \\
\mathrm{NaHSO}_{3}\end{array}$ & $\begin{array}{r}0.50 \% \\
\mathrm{NaHSO}_{3}\end{array}$ \\
\hline Bintje, hietainen urpasavi (Vehkalahti) & 4 vrk. & 6 vrk. \\
\hline Bintje, multava hietamaa (Mikkeli) & $6 n$ & $10 "$ \\
\hline Realta, hietainen urpasavi (Vehkalahti) & $0 "$ & $2 "$ \\
\hline Realta, multava hietamaa (Mikkeli) & $4 "$ & $5 "$ \\
\hline
\end{tabular}

Bintje säilyi kuorittuna paremmin kuin Realta. Molemmat lajikkeet viljeltyinä multavalla hietamaalla säilyivät paremmin kuorittuna kuin hietaisella urpasavella viljellyt. Sulfiittikonsentraation kaksinkertaistaminen pidensi säilyvyyttä n. 2 vrk.

M a k u e rot. Triangelitestillä tutkittiin, aiheuttiko

1) kalimäärän nelinkertaistuminen samalla typpilannoitustasolla

2) typpilannoitteen nelinkertaistuminen samalla kalilannoitustasolla

3) kali- ja typpilannoitusmäärän samanaikaisesti tapahtuva nelinkertaistuminen muutosta perunan makuun. Tätä varten verrattiin triangelitestillä seuraavia koejäseniä pareittain keskenään

\begin{tabular}{|c|c|c|c|c|c|}
\hline 1) & N 50 & $\mathrm{~kg} / \mathrm{ha}$ & $\mathrm{K}_{2} \mathrm{O}$ & 400 & $\mathrm{~kg} / \mathrm{h}$ \\
\hline & N 200 & $"$ & $"$ & 400 & . \\
\hline & N 125 & 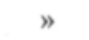 & $"$ & 100 & \\
\hline & N 125 & $n$ & $"$ & 400 & $m$ \\
\hline & N 50 & $"$ & $"$ & 100 & $n$ \\
\hline & N 200 & $n$ & $n$ & 400 & $n$ \\
\hline
\end{tabular}

Keskenään verrattavat näytteet olivat samaa ominaispainoluokkaa, jolloin ominaispainon vaikutus makuun tuli eliminoiduksi. Materiaalina oli hietaisella urpasavella (Vehkalahti) viljelty Bintje ja Realta.

Typpi- ja kalimäärän nelinkertaistuminen samanaikaisesti aiheutti voimakkaan maun perunaan, minkä perusteella perunat olivat erotettavissa vertailunäytteistä. Sen sijaan typpi- tai kalilannoituksen nelinkertaistuminen yksinään ei aiheuttanut makueroa. 
Taulukko 4. Keiton jälkeinen tummuminen hietaisella urpasavella (Vehkalahti) ja multavalla hietamaalla (Mikkeli) eri lannoitustasoilla viljellyssä Bintjessä ja Realtassa arvosteltuna kuorittuna keitetyistä perunoista.

Arvostelussa käytetty asteikko: $0=$ tummumaton, $1=$ hyvin lievästi tummunut, $2=$ hiukan tummunut, 3 = pahasti tummunut, $4=$ pilalle tummunut.

\begin{tabular}{cccccc}
\hline \multicolumn{2}{c}{ Lannoitustaso } & \multicolumn{2}{c}{ Bintje } & \multicolumn{2}{c}{ Realta } \\
\hline $\begin{array}{c}\mathrm{N} \\
\mathrm{kg} / \mathrm{ha}\end{array}$ & $\begin{array}{c}\mathrm{K}_{2} \mathrm{O} \\
\mathrm{kg} / \mathrm{ha}\end{array}$ & Vehkalahti & Mikkeli & Vehkalahti & Mikkeli \\
& & & & & \\
\hline \multirow{2}{*}{50} & 100 & 0 & 0 & 2 & 1 \\
& 200 & 0 & 0 & 2 & 1 \\
& 400 & 0 & 0 & 1 & 0 \\
& 100 & 1 & 0 & 3 & 2 \\
& 200 & 0 & 0 & 3 & 2 \\
& 400 & 0 & 0 & 1 & 2 \\
& 100 & 1 & 1 & 4 & 4 \\
& 200 & 1 & 1 & 3 & 4 \\
& 400 & 0 & 1 & 2 & 3 \\
\hline
\end{tabular}

Taulukko 5. Keiton jälkeinen tummuminen hietaisella urpasavella (Vehkalahti) ja multavalla hietamaalla (Mikkeli) eri lannoitustasoilla viljellyssä Bintjessä ja Realtassa arvosteltuna kuorineen keitetystä perunasta.

Arvostelussa käytetty asteikko: $0=$ tummumaton, $1=$ hyvin lievästi tummunut, $2=$ hiukan tummunut, $3=$ pahasti tummunut, $4=$ pilalle tummunut.

\begin{tabular}{|c|c|c|c|c|c|}
\hline \multicolumn{2}{|c|}{ Lannoitustaso } & \multicolumn{2}{|c|}{ Bintje } & \multicolumn{2}{|c|}{ Realta } \\
\hline$\underset{\mathrm{kg} / \mathrm{ha}}{\mathrm{N}}$ & $\begin{array}{l}\mathrm{K}_{2} \mathrm{O} \\
\mathrm{kg} / \mathrm{ha}\end{array}$ & Vehkalahti & Mikkeli & Vehkalahti & Mikkeli \\
\hline \multirow{3}{*}{50} & 100 & 1 & 1 & 2 & 2 \\
\hline & 200 & 1 & 1 & 2 & 1 \\
\hline & 400 & 1 & 1 & 1 & 1 \\
\hline \multirow{3}{*}{125} & 100 & 3 & 2 & 3 & 3 \\
\hline & 200 & 2 & 2 & 3 & 3 \\
\hline & 400 & 1 & 2 & 3 & 2 \\
\hline \multirow{3}{*}{200} & 100 & 3 & 3 & 3 & 3 \\
\hline & 200 & 3 & 3 & 3 & 3 \\
\hline & 400 & 2 & 1 & 3 & 3 \\
\hline
\end{tabular}




\section{Tarkastelua}

Typpi- ja kalilannoituksen lisäämisen aiheuttama ominaispainon aleneminen on yhdenmukainen muiden tutkimusten kanssa (Agerberg ja Svensson 1961, Baerug 1961, Rowberry ym. 1963, Lujan ja Smith 1964, Svensson 1964, Teich ja Menzies 1964, Andersen 1966, Johansson 1966, Lomakka 1966, Schippers 1968a, Varis 1970b).

Ominaispainon alenemisen seurauksena on jauhoisuuden huonontuminen, jonka ovat todenneet mm. Agerberg ja Svensson (1961), Schippers (1961, 1968a), Svensson (1964), Johansson (1966), Lomakka (1966), VARis (1970b).

Jauhoisuuden väheneminen lannoitusta lisättäessä aiheutti, jauhoisuuden ollessa laadun minimitekijä, myös sadon moitteettoman ruokaperunan \%:isen osuuden pienenemistä.

Perunan maku näyttää olevan vähemmän riippuvainen lannoituksesta kuin jauhoisuus. Esim. typpilannoituksen on todettu vaikuttavan vähän, jos lainkaan perunan makuun (Agerberg ja Svensson 1961, Schippers 1961, Schmitt ja Brauer 1964, Svensson 1964, Johansson 1966). Tosin Lomakan (1966) tutkimuksessa todettiin typpilannoituksen lisäämisen aiheuttavan maun muutoksen. VARIs (1970b) totesi sekä typpi- että kalilannoituksen lisäämisen aiheuttavan maun huonontumisen. Sen sijaan HARraP (1960), RowberRy ym. (1963) ja Johansson (1966), eivät todenneet kaliumlannoituksen lisäämisellä olevan vaikutusta perunan makuun. Kalilähteenä on kaliumsulfaatti todettu paremmaksi kuin kaliumkloridi (LÄhde 1935, EAstwood ja WAtts 1956, Lujan ja Sмith 1964, VARIs 1970b). Tämän tutkimuksen mukaan lannoituksen vaikutus perunan makuun oli verraten vähäinen, kun ominaispainon vaikutus makuun oli eliminoitu vertaamalla triangelitestillä saman ominaispainoluokan perunoita eri lannoitustasoilta: ainoastaan molempien lannoitteiden samanaikainen nelinkertaistaminen aiheutti maun muutoksen perunaan. Määritettäessä kunkin lannoitustason ominaismakua painomäärältään suurimmasta ominaispainoluokasta heijastui yleensä myös ominaispainon aleneminen maun huonontumisena. Realtan kohdalla oli kuitenkin havaittavissa maun arvostelun kohdalla eräitä ristiriitaisuuksia: voimakkaammin lannoitettuja pidettiin jopa maultaan parempina kuin vähemmän lannoitettuja. Tämä johtuu maun arvostelun vaikeudesta attribuuttien tai pisteiden käyttöön perustuvalla arvostelumenetelmällä ja lajikkeen sisäisestä laadun vaihtelusta.

Keiton jälkeistä tummumista esiintyi vähiten pienimmällä typpilannoituksella (50 kg $\mathrm{N} / \mathrm{ha}$ ), joten kalin määrä ei tullut kriittiseksi tällä typpitasolla. Typpilannoitusta lisättäessä lisääntyi myös tummumisalttius, jota voitiin estää kalilannoituksen lisäämisellä. Näin ollen typpilannoituksen lisääminen vaatii vastaavasti kalilannoituksen lisäämistä, jotta tummumista ei esiintyisi. Myös muissa tutkimuksissa on käynyt ilmi, että kasvuolosuhteiden muutoksilla on monin verroin suurempi vaikutus perunan laatuun kuin lannoituksella (Eastwood ja Watts 1956, Stuckey ym. 1964, Teich ja Menzies 1964).

Bintje osoittautui tutkimuksen mukaan kokonaisuutena laadultaan paremmaksi kuin viljelyteknillisesti helpommin hallittava, mutta kasvuolosuhteiden muutoksille herkempi Realta.

\section{Yhteenveto}

Tutkimuksessa selvitettiin typpi- ja kalilannoituksen vaikutusta ruokaperunan laatuun. Kokeessa olivat lajikkeet Bintje ja Realta, jotka viljeltiin kahdella eri kasvupaikalla, Mik- 
kelissä ja Vehkalahdella, yhdeksällä eri lannoitustasolla. Mikkelissä oli maaniaatu multava hietamaa ja Vehkalahdella hietainen urpasavi. Kenttäkokeessa käytetty typpilannoitus oli 50,125 ja $200 \mathrm{~kg} \mathrm{~N} /$ ha kukin yhdistettynä kolmeen eri kalilannoitustasoon: 100, $200 \mathrm{ja} 400 \mathrm{~kg} \mathrm{~K}_{2} \mathrm{O} / \mathrm{ha}$.

Laadun arvostelemiseksi määritettiin keskimääräinen ominaispaino ja suoritettiin ominaispainolajitellusta materiaalista maun ja jauhoisuuden arvostelu. Näiden perusteella laskettiin moitteettoman ruokaperunan osuus eri koejäsenissä. Kullekin lannoitustasolle ominainen maku ja jauhoisuus arvosteltiin painomäärältään suurimman ominaispainoluokan perusteella. Lisäksi tutkittiin lannoituksen vaikutus keiton jälkeiseen tummumiseen ja värin säilymiseen kuorittuna.

Typpi- ja kalilannoituksen lisääminen alensi perunan ominaispainoa, mikä ilmeni perunan laadussa ominaisjauhoisuuden ja maun huononemisena ja moitteettoman ruokaperunan määrän pienenemisenä. Laadultaan parasta perunaa saatiin molemmista lajikkeista molemmilta kasvupaikoilta pienimmällä typpilannoituksella ( $50 \mathrm{~kg} \mathrm{~N} / \mathrm{ha}$ ). Kasvupaikalla oli kuitenkin suurempi vaikutus perunan laatuun kuin lannoituksella.

Keiton jälkeistä tummumista oli vähiten pienimmällä typpilannoituksella ( $50 \mathrm{~kg} \mathrm{~N} / \mathrm{ha}$ ) kalimäärästä riippumatta. Typpilannoitusta lisättäessä tummumistaipumus kasvoi, mutta suuret kalimäärät estivät tummumisen.

Kuoritun perunan säilyvyyteen ei lannoitus vaikuttanut tarkastuksen tapahtuessa 1 vrk:n välein.

\section{KIRJALLISUUTTA}

Agerberg, L. S., Svensson, B. 1961. Potatisens kvävegödsling. Stat. jordbr. förs. Medd. $125: 1$. Andersen, I. L. 1966. Gjødslingsforsøk i potet i Troms og Finnmark. Forsk. Fors. Landbr. 34: 261.

Andersson, B., Stom, S. \& Svensson, B. 1964. Sort- och gödslingsförsök i potatis. Akt. Lantbr.högsk. 25: 1 .

Arenz, B., Grassmann, A. \& Kiessling, L. 1960. Einfluss verschiedener Dügerkombinationen auf Arbeitsvereinfachung, Ertrag und einige Qualitätsmerkmale im Kartoffelbau. Kartoffelbau 11: 9.

BAerug, R. 1961. Stigende mengder nitrogen-, fosfor- og kaliumgjodsel til poteter. Virkning på avlingsstörrelse og matkvalitet. Forsk. Fors. Landbr. 3.

EAstwood, T. \& WATTs, J. 1956. The effect of potash fertilization upon potato chipping quality IV Specific gravity. Am. Potato J. 33: 265.

Ellala, A., Vanhanen, L. \& Kurkela, R. 1970. Pestyn perunan säilyvyys neularei'itetyssä muovissa. J. Sci. Food Agric. 42: 180.

Harrap, F. E. G. 1960: Some aspects of the potash nutrition of the potato. J. Sci. Food Agric. 11: 293.

Hernes, O. \& Elle, Th. 1961. Kombinert sorts- og gjødslingsforsok med poteter. Forskn. Fors. Landbr. 12: 277 .

Itä-Suomen Raakasokeritehdas Oy:n perunan viljelykokeet. Tulokset 1968. 51 p. Kotka.

JoHAnsson, O. 1966: Rapport från pågående växtnäringsförsök med potatis. I Kväve- och fosforsgödsling. Akt. Lantbr. högsk. 13: 1 .

LомаккA, L. 1966. Försök med gödsling av potatis i norra Sverige. Lantbr. högsk. Medd. A. 44: 1.

Lugr, C., Goodjk, G. 1959. Report on the third meeting of the working group "Potato quality research" of EAPR. Versl. I.B.S.O.L. 15: 1.

Lujan, L., Sмrтh, O. 1964. Potato quality XXV. Specific gravity and after cooking darkening of Katahdin potatoes as influenced by fertilizers. Am. Potato J. 41: 274.

LÄHDE, V. 1935. Perunan lannoituskokeiden tuloksia. Maatalouskoelaitoksen kasvinviljelyosastolla vuosina 1931-1934. Valt. Maatal.koet. Tied. 88: 1. 
Rowberry, R. G., Sherrell, C. G. \& Johnston, G. R. 1963. Influence of rates of fertilizer and sources of potassium on the yield, specific gravity and cooking quality of katahdin potatoes. Am. Potato J. 40: 177.

Schippers, P. A. 1961. The influence of nitrogen and potassium fertilization on the cooking quality of potatoes. Eur. Potato J. 4: 224.

1968a. The influence of rates of nitrogen and potassium application on the yield and specific gravity of four potato varieties. Eur. Potato J. 11: 23.

$1968 \mathrm{~b}$. The influence of rates of nitrogen and potassium application on the cooking quality of four potato varieties. Eur. Potato J. 11: 88.

Sснмтtт, L. \& Brauer, A. 1964. Stickstoffdüngung und Qualität der Kartoffel. Mitt. Deut. Landw. Ges. 79: 475 .

Solı, H.-H. 1961. Einfluss der Kalidüngung auf Ertrag und Qualität. Kartoffelbau 12: 11.

Stuckey, I. H., Tucker, R. E. \& Sheehan, J. E. 1964. Cooking qualities of Rhode Island potatoes. Am. Potato J. 41: 1.

Svensson, B. 1964. Matpotatisens kvalitet VII. Inverkan av ammoniumsulfat och kaliumsulfat på matpotatisens avkastning och kvalitet. Landbr. högsk. Medd. A. 22: 1.

Teich, A. H., Menzies, J. A. 1964. The effect of nitrogen, phosphorus and potassium on the specific gravity, ascorbic acid content and chipping quality of potato tubers. Am. Potato J. 41: 169.

VARIS, E. 1970a. Specific gravity sorting as a variation criterion of the cooking quality of potato lots grown under various conditions. Acta Agr. Fenn. 118, 1: 1.

VARIs, E. 1970b. Starch content as a criterion of the cooking quality of potato lots grown under various conditions. Acta Agr. Fenn. 11, 2: 1 . 